THUNDER SHAMAN 
THIS PAGE INTENTIONALLY LEFT BLANK 


\section{THUNDER SHAMAN}

MAKING HISTORY with MAPUCHE SPIRITS in CHILE and PATAGONIA

ANA MARIELLA BACIGALUPO

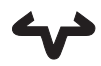

UNIVERSITY OF TEXAS PRESS

Austin 


\section{Copyright (C) 2016 by the University of Texas Press \\ All rights reserved \\ Printed in the United States of America \\ First edition, 2016}

Requests for permission to reproduce material from this work should be sent to:

$$
\begin{gathered}
\text { Permissions } \\
\text { University of Texas Press } \\
\text { P.O. Box 7819 } \\
\text { Austin, TX 78713-7819 } \\
\text { http://utpress.utexas.edu/index.php/rp-form }
\end{gathered}
$$

All images and maps are courtesy of the author.

$\otimes$ The paper used in this book meets the minimum requirements of ANSI/NISO Z39.48-I992 (R I997) (Permanence of Paper).

\section{LIBRARY OF CONGRESS CATALOGING-IN-PUBLICATION DATA}

Bacigalupo, Ana Mariella, author.

Thunder shaman : making history with Mapuche spirits in Chile and Patagonia / Ana Mariella Bacigalupo. - First edition.

$$
\text { pages } \mathrm{cm}
$$

Includes bibliographical references and index.

$$
\begin{aligned}
& \text { ISBN 978-I-4773-0880-6 (cloth : alk. paper) } \\
& \text { ISBN 978-I-4773-0898-I (pbk. : alk. paper) } \\
& \text { ISBN 978-I-4773-088I-3 (library e-book) } \\
& \text { ISBN 978-I-4773-0882-o (non-library e-book) }
\end{aligned}
$$

I. Mapuche Indians_-Patagonia (Argentina and Chile) — Rites and ceremoniesHistory. 2. Shamans-Patagonia (Argentina and Chile) 3. Patagonia (Argentina and Chile) I. Title.

$$
\begin{gathered}
\text { F3126.B33 } 2016 \\
305.898^{\prime} 720827-\mathrm{dc} 23 \\
2015021068
\end{gathered}
$$


For Francisca Kolipi Kurin, who upon seeing this would say, I hope, "I have arrived, dear old ones. I have returned." 
THIS PAGE INTENTIONALLY LEFT BLANK 